\title{
Desmoglein 1 Antibody Measurement
}

National Cancer Institute

\section{Source}

National Cancer Institute. Desmoglein 1 Antibody Measurement. NCI Thesaurus. Code C122114.

The determination of the amount of desmoglein 1 antibody in a biological specimen. 